\title{
(Effect of Pleurotus ostreatus on Pancreatic Beta Cells of Diabetes Mellitus Mice Model)
}

\section{(Efek Pleurotus Ostreatus terhadap Sel Beta Pankreas pada Mencit Model Diabetes Mellitus)}

\author{
NINGRUM WAHYUNI ${ }^{*}$, SYAFRUDIN ILYAS ${ }^{2}$, ALYA AMILA FITRIE $^{3}$ \\ ${ }^{1}$ Biomedical Master Program, Faculty of Medicine, University of North Sumatera, Medan, Indonesia \\ ${ }^{2}$ Department of Biology, Faculty of Mathematics \& Science, University of North Sumatera, Medan, \\ Indonesia \\ ${ }^{3}$ Department of Histology, Faculty of Medicine, University of North Sumatera, Medan, Indonesia
}

Diterima 17 April 2017, Disetujui 12 Juli 2017

\begin{abstract}
Over the last 30 years, the number of people suffering from diabetes mellitus has doubled globally. Adipose tissue dysfunction plays an important role in insulin resistance. Mushroom has been traditionally used to prevent diabetes. This research aims to study the anti-oxidative effect of Pleurotus ostreatus on pancreatic beta cells. This study is an experimental posttest only control group design. The subjects were 24 male wistar mice, divided into six groups. Group P0 was given distilled water and citrate buffer. Group P1 was given high fat diet (HFD) and low dose streptozotocin (STZ). Group P2 and P3 were given HFD and low dose STZ along with Pleurotus ostreatus ethanol extract. Group P4 and P5 were given HFD and low dose STZ, and then given Pleurotus ostreatus ethanol extract. Blood glucose levels and pancreatic beta cells area count were done after treatment. Data obtained was analyzed using one-way ANOVA test. One-way ANOVA test showed significant difference in all the groups $(\mathrm{p}<0.05)$. Post Hoc test results showed difference in blood glucose levels and pancreatic beta cells area count. Pleurotus ostreatus ethanol extract can prevent cellular damage to murine pancreatic beta cells but unable to reverse the damage to the beta cells.
\end{abstract}

Keywords: diabetes mellitus type 2, pancreatic beta cells, pleurotus ostreatus.

Abstrak: Selama 30 tahun terakhir, jumlah orang yang menderita diabetes mellitus telah meningkat dua kali lipat secara global. Disfungsi jaringan adiposa memainkan peran penting dalam resistensi insulin. Jamur telah secara tradisional digunakan untuk mencegah diabetes. Penelitian ini bertujuan untuk mempelajari efek antioksidatif dari Pleurotus ostreatus pada sel beta pankreas. Penelitian ini merupakan desain kelompok kontrol post test eksperimental. Subjek penelitian adalah 24 tikus wistar jantan, dibagi menjadi enam kelompok. Kelompok P0 diberi air suling dan dapar sitrat. Kelompok P1 diberi diet lemak tinggi (HFD) dan streptozotocin dosis rendah (STZ). Kelompok P2 dan P3 diberi HFD dan dosis rendah STZ bersama dengan ekstrak etanol Pleurotus ostreatus. Kelompok P4 dan P5 diberi HFD dan STZ dosis rendah, dan kemudian diberi ekstrak etanol Pleurotus ostreatus. Kadar glukosa darah dan jumlah area sel beta pankreas dilakukan setelah perlakuan. Data yang diperoleh dianalisis menggunakan uji ANOVA satu arah. Uji ANOVA satu arah menunjukkan perbedaan yang signifikan dalam semua kelompok $(\mathrm{p}<0,05)$. Hasil uji post Hoc menunjukkan perbedaan kadar glukosa darah dan jumlah area sel beta pankreas. Ekstrak etanol Pleurotus ostreatus dapat mencegah kerusakan sel pada sel beta pankreas murine tetapi tidak dapat membalikkan kerusakan sel beta.

Kata kunci: diabetes melitus tipe 2, sel beta pankreas, pleurotus ostreatus.

* Correspondence Author, Hp: 081265022696

Email: ningrumwahyuni@gmail.com 


\section{INTRODUCTION}

DIABETES mellitus (DM) is a clinically and genetically heterogeneous group of disorders characterized by abnormally high levels of glucose in the blood $^{(1)}$. Over the last 30 years, the number of people suffering from diabetes mellitus has doubled globally and becomes a challenge in several countries $^{(2)}$.

DM type 2 is the most common type of diabetes ${ }^{(3)}$, amounting to $90 \%$ of the total diabetes case in $2010^{(2)}$. The DM type 2 prevalence has reached epidemic proportion worldwide and has become a world health threat ${ }^{(3,4)}$. DM type 2 is more prevalent in developing countries compared to developed countries with $80 \%$ of the people with DM type 2 is in developing countries. Among 10 countries predicted to have the highest incidence of DM type 2 in 2030, 5 is in Asia with China, India, Pakistan, Indonesia, and Bangladesh making the list ${ }^{(2)}$.

Among the factors contributing to the incidence of DM type 2 are obesity, genetic factors, smoking and alcohol consumption ${ }^{(2,4)}$, sedentary lifestyle ${ }^{(3)}$, sleeping disorders and depression ${ }^{(2)}$. Involvement of high fat diet in DM type 2 has been reported by decades ${ }^{(5)}$.

Recent studies showed that obesity may cause DM type 2 through involvement of pro-inflammatory cytokines (TNF \& IL-6), insulin resistance, impaired fatty acid metabolism, and impaired cellular process such as mitochondria dysfunction ${ }^{(6)}$. The type of fat in high fat diet affects the membrane fatty acid composition and may affect cellular membrane function, including membrane instability, ion permeability, and insulin receptor binding affinity ${ }^{(5)}$.

Adipose tissue dysfunction plays an important role in insulin resistance ${ }^{(7)}$. Adipose tissue secretes TNF $\alpha$ along with monocytes and lymphocytes, where it is involved in inflammatory response and is associated with insulin resistance, obesity, and diabetes ${ }^{(3)}$. Insulin resistance contributed by inflammation on skeletal muscle and lipid metabolism, is the main metabolic abnormality in most of DM type 2 patients ${ }^{(8)}$, where intracellular lipid accumulation in the skeletal muscle and liver is observed in both man and murine. The lipid accumulation causes disruption in GLUT4, which reduces the amount of glucose into the cell and lowers glucose oxidation and glycogen synthesis ${ }^{(9)}$.

STZ administration induce increase of food and water intake, static mass gain, and increase in blood glucose level ${ }^{(10)}$. Microscopic observation of STZ induced mice showed histomorphologic abnormality of the pancreas. Langerhans Island cells were misshaped, reduced in size, and reduction in pancreatic endocrine cells ${ }^{(11)}$. Polysaccharide (beta glucan) in mushrooms can recover pancreatic tissue function by increasing insulin secretion from functional $\beta$-cells, which lowers the blood glucose levels and repair peripheral cells sensitivity to circulating insulin ${ }^{(12,13)}$.

Pleurotus species is a member of phylum Basidiomycota. Pleurotus ostreatus increase the antioxidative enzyme which reduces oxidative damage in human. Pleuratus ostreatus contains polyphenols known to hamper mutagenic and carcinogenic effect ${ }^{(14)}$. Ikrimah in 2012, showed that oyster mushroom extract was proven to regenerate Langerhans Island cells shown with increase of pancreatic mass and lower blood glucose levels ${ }^{(15)}$. Based on the observations above, it is interesting to see the effect of Pleurotus ostreatus on DM type 2 induced mice pancreatic $\beta$-cells with high fat diet and low-dose streptozotocin.

\section{MATERIALS AND METHODS}

METHODS. Reaserch Design. This study is an experimental posttest only control group design. The study was conducted from November 2013 until January 2014.

Study Subjects. The subjects were 24 male wistar

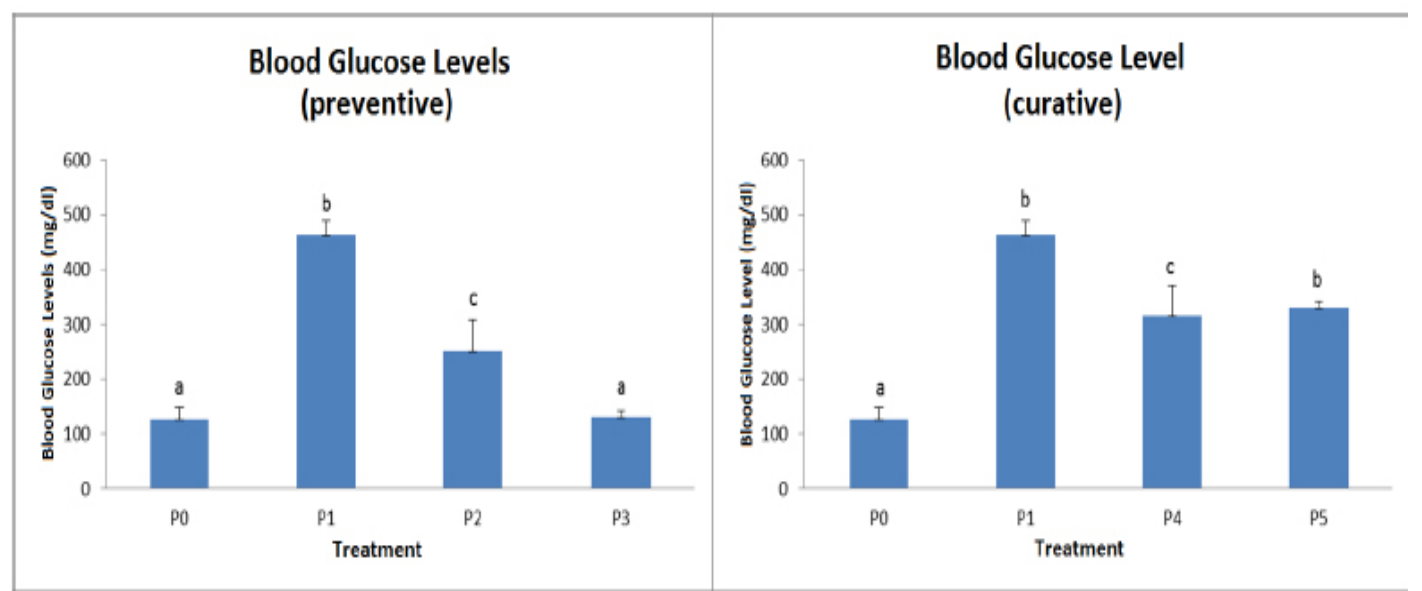

Picture 1. Average blood glucose levels of the preventive and curative group. 
mice, divided into six groups ( $\mathrm{n}=4 /$ treatment). Group $\mathrm{P}_{0}$ was given distilled water and citrate buffer. Group $\mathrm{P}_{1}$ was given high fat diet and low dose streptozotocin (STZ) of $30 \mathrm{mg} / \mathrm{kg}$ body weight. Group $\mathrm{P}_{2}$ and $\mathrm{P}_{3}$ were given high fat diet and low dose STZ along with Pleurotus ostreatus ethanol extract $(200 \mathrm{mg} / \mathrm{kg} \mathrm{BW} /$ day and $250 \mathrm{mg} / \mathrm{kg} \mathrm{BW/day,} \mathrm{respectively).} \mathrm{Group} \mathrm{P}_{4}$ and $\mathrm{P}_{5}$ were given high fat diet and low dose STZ, and then given Pleurotus ostreatus ethanol extract (200 $\mathrm{mg} / \mathrm{kg} \mathrm{BW} /$ day and $250 \mathrm{mg} / \mathrm{kg} \mathrm{BW/day,} \mathrm{respectively).}$

Preparation of Pleurotus ostreatus Extract. Pleurotus ostreatus extract was prepared as followed: all parts of the mushroom cut into small strips and then dried to be a powder. The powder was macerated in $96 \%$ ethanol for 72 hours. The ethanolic extract was then evaporated in a rotary evaporator to get concentrated Pleurotus ostreatus extract. The concentrated Pleurotus ostreatus extract was then dried using freeze dryer to evaporate the remaining solvent. The dried Pleurotus ostreatus extract then made into suspension with CMC solvent.

Treatment. All 24 mice were randomly assigned to 6 groups of 4 mice each. The groups are as follows: $\mathrm{P}_{0}$ : Aquadest + normal feed (56 days)+citrate buffer injection (day 15 \& 22); P1: high fat diet (14 days) + STZ injection (30 mg/kg BW day 15 \& 22); P2 $=$ high fat diet $\&$ Pleurotus ostreatus ethanol extract $200 \mathrm{mg} / \mathrm{kg}$ BW (14 days) $+\mathrm{STZ}$ injection (30 mg/ kg BW day 15 \& 22)+Pleurotus ostreatus ethanol extract $200 \mathrm{mg} / \mathrm{kg} \mathrm{BW}$ (7 days); $\mathrm{P}_{3}=$ high fat diet \& Pleurotus ostreatus ethanol extract $250 \mathrm{mg} / \mathrm{kg} \mathrm{BW}$ (14 days) + STZ injection $(30 \mathrm{mg} / \mathrm{kg}$ BW day 15 \& 22) + Pleurotus ostreatus ethanol extract $200 \mathrm{mg} / \mathrm{kg} \mathrm{BW}$ (7 days); $\mathrm{P}_{4}=$ high fat diet (14 days) + STZ injection (30 $\mathrm{mg} / \mathrm{kg} \mathrm{BW}$ day $15 \& 22)+$ Pleurotus ostreatus ethanol extract $200 \mathrm{mg} / \mathrm{kg} \mathrm{BW}$ (28 days); $\mathrm{P}_{5}=$ high fat diet (14 days) + STZ injection $(30 \mathrm{mg} / \mathrm{kg} \mathrm{BW}$ day $15 \&$ 22)+Pleurotus ostreatus ethanol extract $250 \mathrm{mg} / \mathrm{kg}$ BW (28 days).

Examination Procedure. The mice pancreatic $\beta$-cells were extracted and made into immunohistochemistry slide from a paraffin block. The slide is then analyzed under a light microscope with automatic camera (Matsuoka Nissei, Japan), under 400x magnification. The images were analyzed using ImageJ (National Institute of Health, USA). The blood glucose levels were analyzed using Diasys kit and spectrophotometer.

Data Analysis. The data were analyzed statistically using One Way ANOVA. If ANOVA showed $\mathrm{p}<0.05$, then Post Hoc test will be performed to see differences between treatment groups. In this experiment, only $\alpha$ $\leq 0.05$ is considered statistically significant.

Ethical Clearance. This study has received ethical clearance from the Animal Research Ethics Committees (AREC), Faculty of Science and Mathematics, University of North Sumatera under No. 122/KEPH-FMIPA/2013.

\section{RESULT AND DISCUSSION}

The average blood glucose level for $\mathrm{P}_{0}$ is $127.75 \mathrm{mg} /$ $\mathrm{dL}, \mathrm{P}_{1}$ is $463 \mathrm{mg} / \mathrm{dL}, \mathrm{P}_{2}$ is $250.75 \mathrm{mg} / \mathrm{dL}$, and $\mathrm{P}_{3} 131.25$ $\mathrm{mg} / \mathrm{dL}$. There is a significant difference in blood glucose levels between $\mathrm{P}_{0}$ with $\mathrm{P}_{1}$ and $\mathrm{P}_{2}$. However, no significant difference observed between $\mathrm{P}_{0}$ and $\mathrm{P}_{3}$. The average pancreatic $\beta$-cell area for $\mathrm{P} 0$ is $74.38 \%, \mathrm{P}_{1}$ is $23.04 \%, \mathrm{P}_{2}$ is $49.16 \%$, and $\mathrm{P}_{3}$ is $62.10 \%$. The graphic showed that there is a significant difference between $\mathrm{P}_{0}$ with $\mathrm{P}_{1}$ and $\mathrm{P}_{2}$. However, no significant difference observed between $\mathrm{P}_{0}$ and $\mathrm{P}_{3}$.

The average blood glucose level for $\mathrm{P}_{0}$ is 127.75 $\mathrm{mg} / \mathrm{dL}, \mathrm{P}_{1}$ is $463 \mathrm{mg} / \mathrm{dL}, \mathrm{P}_{4}$ is $314 \mathrm{mg} / \mathrm{dL}$, and $\mathrm{P}_{5}$ $331 \mathrm{mg} / \mathrm{dL}$. There is a significant difference in blood glucose levels between $\mathrm{P}_{0}$ with $\mathrm{P}_{1}, \mathrm{P}_{4}$, and $\mathrm{P}_{5}$. However, no significant difference observed between $\mathrm{P} 1$ and $\mathrm{P} 5$.

The average pancreatic $\beta$-cell area for $P_{0}$ is $74.38 \%, \mathrm{P}_{1}$ is $23.04 \%, \mathrm{P}_{4}$ is $28.63 \%$, and $\mathrm{P}_{5}$ is $32.37 \%$. The graphic showed that there is a significant difference between $\mathrm{P}_{0}$ with $\mathrm{P}_{1}, \mathrm{P}_{4}$, and $\mathrm{P}_{5}$. However,

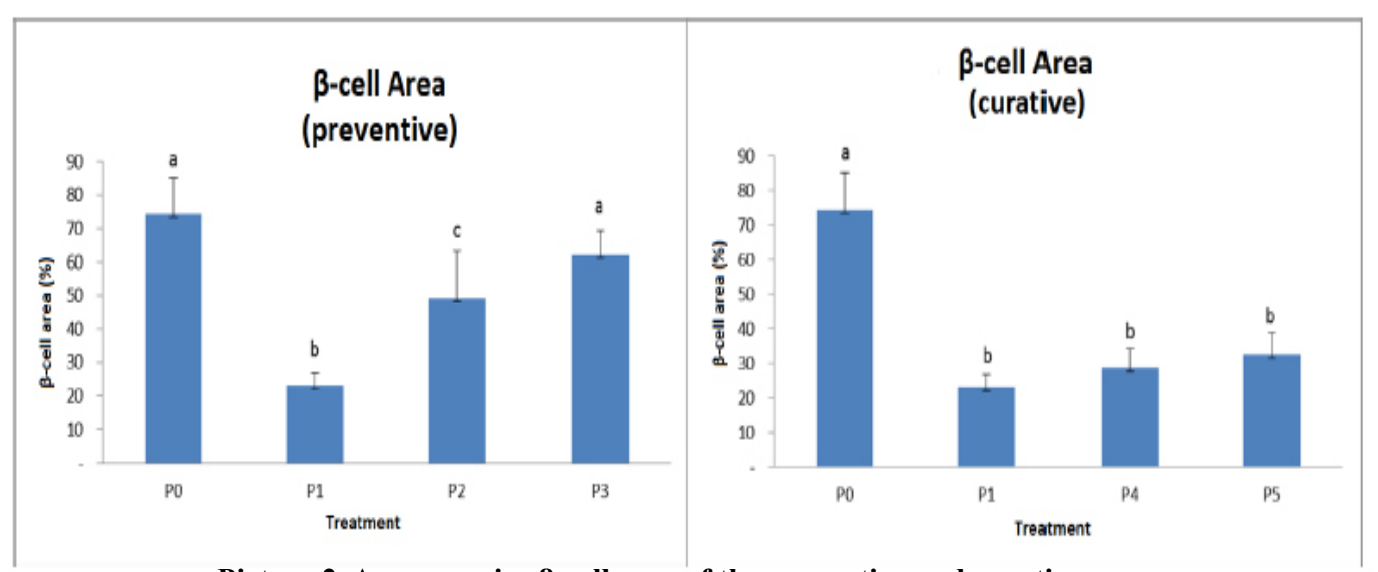

Picture 2. Average mice $\beta$-cell area of the preventive and curative group. 


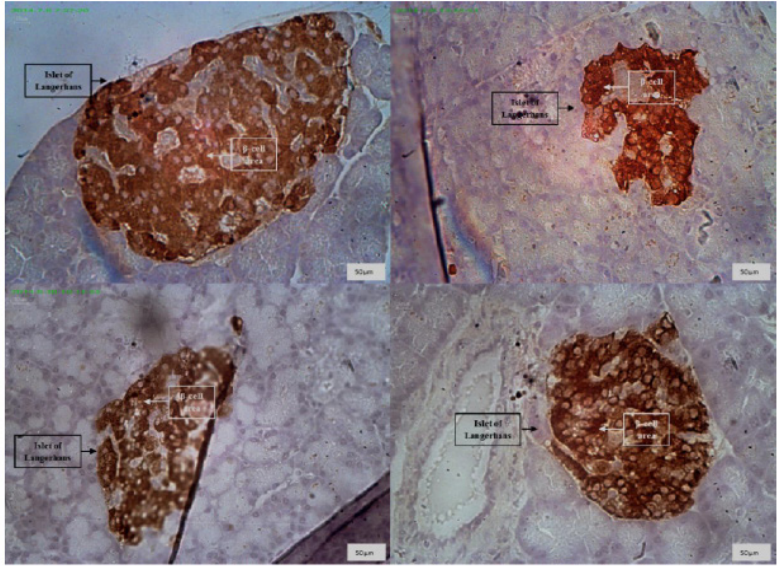

Picture 3. Overview of the pancreatic $\beta$-cells. Clockwise, $P_{0}$ with $74.38 \%$ area; $P_{1}$ with $23.04 \%$; $P_{3}$ with $62.10 \%$; $P_{2}$ with $49.16 \%$. IHC, $400 x$.

no significant difference observed between $\mathrm{P}_{1}$ with $\mathrm{P}_{4}$ and $\mathrm{P}_{5}$.

Pancreatic $\beta$-cell damage was highest for $\mathrm{P}_{1}$, the group given high fat diet and low-dose STZ. This resulted in significantly higher blood glucose level in $\mathrm{P}_{1}$ compared to other groups. Similar results were obtained by Srinivasan (2005), where mice fed with high fat diet for 2 weeks and given $35 \mathrm{mg} / \mathrm{kg} \mathrm{BW} \mathrm{STZ}$ injection gives the closest resemblance to DM type 2 in an animal model. Zhang, et al. also showed that feeding high fat feed followed by STZ injection of $30 \mathrm{mg} / \mathrm{kg} \mathrm{BW}$ twice was a more stable way to induce DM type 2 in animal models ${ }^{(16)}$.

Streptozotocin has been used as a diabetic inducing agent. STZ alkylates DNA via GLUT2 and causing DNA damage ${ }^{(17)}$. Kakkar, et al. observed that STZ-induced mice has increased antioxidative enzyme activity and increased oxidative stress caused pancreatic tissue damage and caused diabetes mellitus ${ }^{(18)}$.

Damage to the pancreatic $\beta$-cells area in the preventive groups $\left(\mathrm{P}_{2}\right.$ and $\left.\mathrm{P}_{3}\right)$ were less compared to $\mathrm{P}_{1}(\mathrm{p}<0.05)$ and pancreatic $\beta$-cells area of $\mathrm{P}_{3}$ is not very different to $\mathrm{P}_{0}$. The blood glucose levels results were also showed similar pattern in the three groups. A study done by Nosal'ova, et al. (2001) showed that Pleurotus ostreatus pleuran extract increases the antioxidative enzyme activity, which leads to reduction of colonic glutathione and reduces precancerous lesion in the colon ${ }^{(19)}$. Similar results were obtained from a study done by Jayakumar et al. in 2006, where CCl4--induced mice were given white oyster mushroom extract and showed significant increase in antioxidative enzyme ${ }^{(20)}$.

Pancreatic $\beta$-cell damage in the curative $\mathrm{P}_{4}$ and $\mathrm{P}_{5}$ groups showed similar result to that of $\mathrm{P}_{1}$. The blood glucose levels in the curative $\mathrm{P}_{4}$ and $\mathrm{P}_{5}$ groups

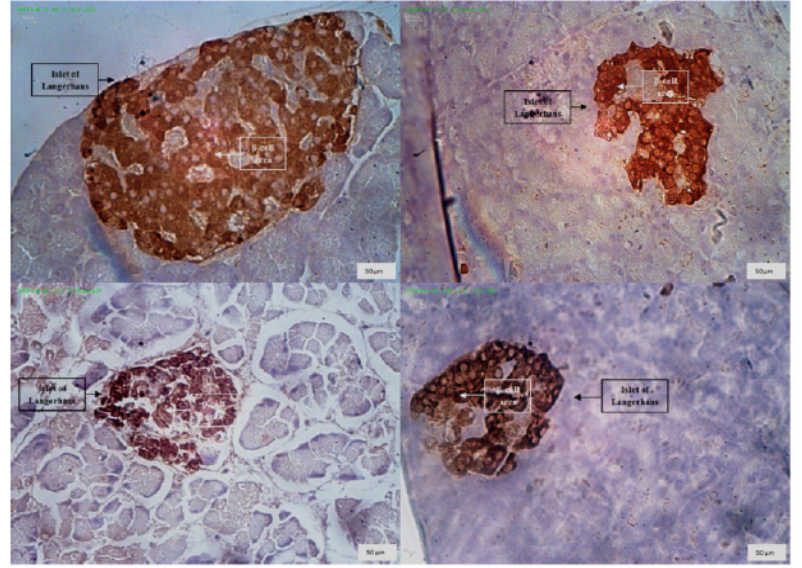

Picture 4. Overview of the pancreatic $\beta$-cells. Clockwise, $P_{0}$ with $74.38 \%$ area; $P_{1}$ with $23.04 \%$; $P_{5}$ with $32.37 \%$; $P_{4}$ with $28.63 \%$. IHC, $400 x$.

also showed similar result to that of $\mathrm{P}_{1}$. STZ alkylates DNA via GLUT2 and causing DNA damage. The DNA damage leads to reduced synthesis and secretion of insulin ${ }^{(17)}$. Pancreatic $\beta$-cell analysis on groups $\mathrm{P}_{4}$ and $\mathrm{P}_{5}$ showed less $\beta$-cells area due to damage caused by high fat diet and low-dose STZ injection. Though white oyster mushroom extract were given as a curative treatment, it did not show significant effect when compared to the positive control group $\left(\mathrm{P}_{1}\right)$. This result showed that the white oyster mushroom extract did not have significant regenerative effect on pancreatic $\beta$-cells.

\section{CONCLUSION}

This research aims to study the effect of white oyster mushroom extract on male wistar mice pancreatic $\beta$-cells induced with high fat diet and streptozotocin induced DM type 2. The results showed that the Pleurotus ostreatus ethanol extract can prevent pancreatic $\beta$-cell damage but unable to restore damaged $\beta$-cells. Further studies with various dosages and longer study time are needed.

\section{REFERENCES}

1. Harris MI. Definition and classification of diabetes mellitus and the criteria for diagnosis. In: Le Roith D, Taylor SI, Olefsky JM, editors. Diabetes Mellitus, A Fundamental and Clinical Text. Philadelphia: Lippincot William \& Wilkins; 2004. 457-72.

2. Chen L, Magliano DJ, Zimmet PZ. The worldwide epidemiology of type 2 diabetes mellitus -present and future perspectives. Nature Reviews Endocrinology. 2012. 8(4): 228-36.

3. Yufang B, Wang T, Xu M, Xu Y, Li M, Lu J, et al. Advanced research on risk factors of type 2 diabetes. 
Diabetes Metab Res Rev. 2012. 28 (Suppl 2): 32-9.

4. Ramachandran A, Snehalatha C, Shetty AS, Nanditha A. Trends in prevalence of diabetes in Asian countries. World Journal of Diabetes. 2012. 3(6):110-7.

5. Choi HK, Willett WC, Stampfer MJ, Rimm E, Hu FB. Dairy consumption and risk of type 2 diabetes mellitus in Men. Arch Intern Med. 2005. 165: 997-1003.

6. Risérus U, Willett WC, Hu FB. Dietary fats and prevention of type 2 diabetes. Progress in Lipid Rresearch. 2009.48(1):44-51.

7. Eckel RH, Kahn SE, Ferrannini E, Goldfine AB, Nathan DM, Schwartz MW, et al. Obesity and type 2 diabetes: what can be unified and what needs to be individualized?. Diabetes care. 2011. 34(6):1424-30.

8. Snel M, Jonker, JT, Schoones J, Lamb H, de Roos A, Pijl $\mathrm{H}$, et al. Ectopic fat and insulin resistance: pathophysiology and effect of diet and lifestyle interventions. International Journal of Endocrinology. 2012.

9. Glass CK, Olefsky J. Inflammation and lipid signaling in the etiology of insulin resistance. Cell Metabolism. 2012. 15(5):635-45.

10. Wolf G. Role of fatty acids in the development of insulin resistance and type 2 diabetes mellitus. Nutrition reviews. 2008. 66(10):597-600.

11. Wei M, Ong L, Smith MT, Ross FB, Schmid K, Hoey AJ, et al. The Streptozotocin-diabetic rat as a model of the chronic complications of human diabetes. Heart, Lung \& Circulation. 2003. 12(1): 44-50.

12. Tian HL, Wei LS, Xu ZX, Zhao RT, Jin DL, Gao JS. Correlations between blood glucose level and diabetes signs in streptozotocin induced diabetic mice. Global J Pharmacol. 2010. 4(3): 111-6.

13. Rathee S, Rathee D, Rathee D, Kumar V, Rathee V. Mushrooms as therapeutic agents. Revista Brasileira de Farmacognosia. 2012. 22(2): 459-74.
14. De Silva DD, Rapior S, Hyde KD, Bahkali AH. Medicinal mushrooms in prevention and control of diabetes mellitus. Fungal Diversity. 2012. 56:1-29.

15. 15. Patel Y, Naraian R, Singh V. Medicinal properties of Pleurotus Species (Oyster Mushroom): A Review. 2012. World Journal of Fungal and Plant Biology. 2012. 3 (1): 1-12.

16. Ikrimah D. Inovasi pengembangan terapi autoregenerasi berbasis mobilisasi hematopoietic stem cell pada mencit model DM menggunakan ekstrak jamur tiram (Pleurotus ostreatus) [skripsi]. Malang: Fakultas Kedokteran Universitas Brawijaya; 2012.

17. Zhang M, Lv XY, Li J, Xu ZG, Chen L. The characterization of high-fat diet and multiple lowdose streptozotocin induced type 2 diabetes rat model. Experimental Diabetes Research. 2008.

18. Szkudelski T. The mechanism of alloxan and streptozotocin action in B cells of the rat pancreas. Physiological Research. 2001. 50:536-46.

19. Kakkar R, Mantha SV, Radhi J, Prasad K, Kalra J. Increased oxidative stress in rat liver and pancreas during progression of streptozotocin-induced diabetes. Clinical Science. 1998. 94: 623-32.

20. Nosál'ová V, Bobek P, Cerná S, Galbavý S, Stvrtina S. Effects of pleuran ( $\beta$-Glucan Isolated from Pleurotus ostreatus) on experimental colitis in rats. Physiological Research. 2001. 50: 575-81.

21. Jayakumar T, Ramesh E, Geraldine P. Antioxidant activity of the oyster mushroom, Pleurotus ostreatus, on CCl4-induced liver injury in rats. Food and Chemical Toxicology. 2006. 44 (12):1989-96. 